\title{
SUETÔNIO, DOS GRAMÁTICOS
}

\author{
$\begin{array}{ll}\text { Marcos Martinho* } & \text { *Universidade de São } \\ & \text { Paulo }\end{array}$
}

RESUMO: O Dos gramáticos de Suetônio divide-se em duas partes: na primeira, o autor narra a introdução, desenvolvimento, florescimento e declínio da gramática em Roma (1-4); na segunda, expõe a biografia de vinte professores de gramática, que ensinaram na Cidade entre o início do séc. I a.C. e meados do século seguinte (5-24). Quanto à primeira parte, procuro mostrar que Suetônio adota conceitos fisicistas ou naturalistas para narrar a história da gramática em Roma, de modo que aquela se possa comparar à vida de um ser vivo. Assim, a exposição de Suetônio revela-se, na verdade, antes biográfica que historicista. Quanto à segunda parte, procuro mostrar que o Biógrafo se interessa por gramáticos que não só escreveram sobre sua arte no ócio, mas a ensinaram por ofício, isto é, por professores de gramática. Daí, seleciono e comento os elementos narrativos relacionados à docência, a saber: os métodos de ensino, o lugar de ensino, o número e qualidade dos alunos, os preços e honorários dos professores. Por fim, apresento tradução anotada do texto de Suetônio.

PALAVRAS-CHAVE: gramáticos latinos; história da gramática; biografia; Suetônio.

\section{SUÉTONE, DE GRAMMATICIS}

RÉSUMÉ: Le De grammaticis de Suétone peut être divisé en deux parties: dans la première, l'auteur raconte l'introduction, développement, fleurissement et déclin de la grammaire à Rome (1-4); dans la deuxième, il expose la biographie de vingt professeurs de grammaire qui ont enseigné dans la Ville entre le début du I ${ }^{\text {er }}$ s. av. J.-C. et le milieu du siècle suivant (5-24). Quant à la première partie, j'essaie de montrer que Suétone adopte des concepts physiques ou naturalistes pour raconter l'histoire de la grammaire à Rome, de manière que celle-là 
1. A divisão é bem assinalada pelos termos com que Suetônio abre cada parte: a primeira, com a palavra grammatica

"gramática" $(1,1)$, a segunda, com a expressão clari professores "professores ilustres" $(4,11)$. puisse être comparée à la vie d'un être vivant. De la sorte l'exposé de Suétone se révèle être plutôt biograhique que historique. Quant à la deuxième partie, j'essaie de montrer que le Biographe s'intéresse aux grammairiens qui non seulement ont écrit sur leur art dans le loisir, mais l'ont enseigné par devoir, c'est à dire, aux professeurs de grammaire. Alors je repère et examine les éléments du récit qui sont en rapport avec l'enseignement, à savoir : les méthodes pédagogiques, le lieu de l'enseignement, le nombre et la nature des élèves, les prix et les salaires des professeurs. Finalement je présente une traduction annotée du texte de Suétone.

MOTS-CLEFS: grammairiens latins; histoire de la grammaire; biographie; Suétone.

\section{APRESENTAÇÃo}

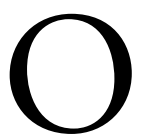

Dos gramáticos de Caio Suetônio Tranqüilo (c. 69

- 126/141 d.C.) divide-se claramente em duas partes: na primeira, o autor narra a introdução, desenvolvimento e florescimento da gramática em Roma (1-4); na segunda, expóe a biografia de vinte professores de gramática, que ensinaram na Cidade entre o início do séc. I a.C. e meados do século seguinte (5-24). ${ }^{1}$ Se na segunda parte narra a vida dos gramáticos, talvez se possa dizer, de modo figurado, que, na primeira, narra a vida da gramática mesma. Seja como for, é a segunda parte que dá nome à obra, a qual, não por acaso, é de longe a mais longa.

\section{A) A VIDA DA GRAMÁTICA}

Na primeira parte, pois, Suetônio conta que o primeiro a introduzir em Roma o estudo da gramática foi Cratete de Malo, que lá fez audições e dissertaçôes e, assim, aos romanos serviu de exemplo para imitarem; daí, porém, observa que a imitação foi parcial (2). Em seguida, conta que a gramática foi aparelhada e desenvolvida sob todo aspecto por Élio Estilão e Sérvio Clódio, um e outro de grande e vária experiência no ensinamento $(3,1)$. Enfim, conta que o prestígio da arte gramatical e o cuidado com ela cresceram 
mais e mais, de modo que ela tenha atraído o interesse dos varões mais ilustres, e as escolas de gramática se tenham multiplicado em Roma e também nas províncias (3, 4-6).

Assim, Suetônio parece narrar o aperfeiçoamento da gramática em Roma, dividindo-o em três tempos. No primeiro tempo, o estudo da gramática foi introduzido na Cidade, mas os romanos acolheram-no de modo parcial; no segundo tempo, a gramática foi aparelhada e desenvolvida de modo integral; no terceiro tempo, o prestígio da arte gramatical e o cuidado com ela cresceram de tal modo que as escolas de gramática se alastraram por toda parte em Roma e também nas províncias. Demais, Suetônio parece esboçar um quarto tempo, ao notar que certos exercícios, por meio dos quais o gramático outrora preparava os alunos para as aulas do rétor, já se omitem em seu tempo pela indolência e falta de facúndia de alguns; pois alunos houve que, nos tempos da juventude de Suetônio, declamassem num dia, disputassem no outro e, nos tempos dos pais dele, passassem imediatamente do estabelecimento do gramático ao fórum (4, 6-10).

Em suma, Suetonio parece conceber a história da gramática em Roma como um caminho para o aperfeiçoamento que se divide em três tempos, senão em quatro, isto é, em três tempos consumados: o tempo da introdução da gramática, o do desenvolvimento, o do florescimento, e num tempo incipiente: o tempo do declínio.

Ora, antes de tudo, essa maneira de conceber a história de uma arte é comum a outros autores; em latim, antes de Suetônio, é comum a Cícero e também Quintiliano. De fato, Cícero (106-43 a.C.), no Bruto, trata o aperfeiçoamento das artes, ${ }^{2}$ dividindo-o em três tempos; não da arte gramatical, porém, senão de outras: escultura, pintura e poesia. Diz que é a mesma a razão nestas, ${ }^{3}$ porque nelas todas nada foi, a um tempo só, tanto descoberto como aperfeiçoado. ${ }^{4}$ Pois, na escultura, como ensina, as imagens de Cânaco são demasiado rígidas para imitarem a verdade; em seguida, as de Calâmide são duras, mas mais maleáveis que as de Cânaco, e as de Mirão ainda não são suficientemente chegadas à verdade, mas já não hesitamos em chamá-las belas; por fim, as de Policlito são ainda mais belas e já plenamente perfeitas. Assim também, na pintura, Zêuxis,
2. cf. 18, 69: et quaerendum esse aliquid perfectius; 18, 70: et iam plane perfecta; ib.: iam perfecta sunt omnia; 18 , 71: nihil est enim simul et inventum et perfectum; 19, 76: perfectior.

3. 18, 70: Similis in pictura ratio est.

4. 18, 71: Et nescio an reliquis in rebus omnibus idem eveniat: nibil est enim simul et inventum et perfectum. 
5. XII 10, 1: Plurimum tamen inuicem differunt: nec solum specie, ut signum signo et tabula tabulae et actio actioni, sed genere ipso; 10, 7: Similis in statuis differentia; 10,10 : In oratione uero si species intueri uelis [...]. Sed fuere quaedam genera dicendi.

6. XII 10, 2: Suos autem haec operum genera quae dico, ut auctores [...] atque ideo nondum est perfectus

7. XII 10, 2: partim condicione uel temporum uel locorum; 10, 10: Sed

fuere quaedam genera dicendi condicione temporum; 10, 11: non multum inter se distantium tempore oratorum; 10,12 : suorum homines temporum.
Polignoto, Timante não empregam mais que quatro cores, mas são louváveis pelas formas e linhas; todavia, em Equíão, Nicômaco, Protógenes, Apeles, tudo já está aperfeiçoado. Na poesia, a Odisséia de Lívio é assim tal como alguma obra de Dédalo, e as peças dele não são suficientemente dignas de serem relidas; todavia, a Guerra púnica de Névio deleita como se fora obra de Mirão; é para admitir, porém, que Ênio seja mais perfeito que Névio $(18,70$ - 19, 76). Em suma, no primeiro tempo, estão as imagens de Cânaco, bem como a epopéia de Lívio, muito rígidas ainda; no segundo, as imagens de Calâmide ou de Mirão, bem como a epopéia de Névio, já mais maleáveis, mas algo duras ainda; no terceiro, as imagens de Policlito, bem como a epopéia de Ênio, já plenamente perfeitas.

Quintiliano (c. 30 - c. 96 d.C.), por sua vez, pretende mostrar como quadros, estátuas e discursos oratórios diferem entre si pelo gênero, ${ }^{5}$ de modo que cada gênero de obra tenha seus autores, e por isso não haja autor perfeito. ${ }^{6}$ Ao expor, porém, os gêneros de pintura, escultura e oratória, distingue três deles, mostrando como cada um despontou ao seu tempo ${ }^{7}$ de modo que acrescentasse à arte algo seu. $\mathrm{Na}$ pintura, as obras de Polignoto e Aglaofonte são quase rudimentos e como que primórdios da arte que logo havia de existir (XII 10, 3). Depois, Zêuxis e também Parrásio acrescentaram muitíssimo à arte (XII 10, 4). Foi, porém, cerca de Filipo e até aos sucessores de Alexandro que a pintura floresceu; pois Protógenes é o que mais sobressai no cuidado, Pânfilo e também Melântio na racionalidade, Antífilo na facilidade, Teão de Samo na concepção das visões que se chamam phantasíai, Apeles no engenho e graça (XII 10, 6). $\mathrm{Na}$ escultura, estátuas mais duras fizeram Calão e Hegésias; em seguida, já menos rígidas, Calâmide, e ainda mais maleáveis que as anteriores, Mirão; por fim, a diligência e decoro sobressaem em Policlito, a que mais de um atribui a palma, ainda que pensem que lhe falta peso; o que faltou a Policlito, porém, se dá a Fídias e Alcâmenes, de que aquele sobressai pela beleza; chegam-se à verdade Lisipo e Praxíteles, ao passo que Demétrio foi mais amante da verossimilhança que da beleza (XII 10, 7-9). No discurso oratório, houve, primeiro, gêneros de discurso que fossem mais rugosos, mas apresentassem grande vigor de engenho, 
de onde saíram Lélio, Escipião o Africano, Catão e os Gracos, que corresponderiam a Polignoto ou Calão. Depois, detiveram a forma intermediária Crasso, Hortênsio. Enfim, floresceu enorme produção de oradores, onde encontramos o vigor de César, a índole de Célio, a sutileza de Calídio, a diligência de Polião, a dignidade de Messala, a sacralidade de Calvo, a gravidade de Bruto, a agudeza de Sulpício, o acerbo de Cássio (XII 10, 10-1). Assim, também Quintiliano parece tratar o aperfeiçoamento das artes, dividindo-o em três tempos: o tempo dos rudimentos e primórdios $;^{8}$ o tempo intermediário, ${ }^{9}$ ou tempo dos acréscimos; ${ }^{10}$ o tempo do florescimento. ${ }^{11}$

Em grego, Políbio (c. 210 - c. 126 a.C.) distingue princípio, desenvolvimento e florescimento e também deterioração; não de artes, porém, mas de constituições políticas. $\mathrm{Na}$ verdade, tendo distinguido seis gêneros destas (VI 4, 1-6; cf. VI 3, 5-12), e tendo daí explicado o modo como uns são gerados dos outros, uns nascem dos outros (VI 4, 7-10), Políbio adverte de que só quem contempla o modo como cada constituição nasce é capaz de contemplar o desenvolvimento, florescimento e transformação e, daí, o fim de cada uma (VI 4, 11-2). Por isso, estende-se num excurso (VI 6, 1 - 9, 9), em que expõe o arrazoado relativo ao modo como as constituições políticas se transformam umas nas outras segundo a natureza, ${ }^{12}$ ou ainda, o ciclo das constituições políticas, ${ }^{13}$ a economia natural ${ }^{14}$ segundo a qual estas se transformam umas nas outras, são substituídas umas pelas outras.

Ora, chama a atenção que Políbio insista na noção de natureza, ora empregando o verbo phýesthai "nascer" (VI 4, 8. 12; 5, 4. 10), p. ex., ao perguntar-se de onde nascem as constituiçôes políticas; ora empregando o substantivo phýsis "natureza" (VI 9, 10; 57, 1), p. ex., ao expor a economia natural segundo a qual as constituiçôes políticas se transformam; ora empregando a expressão katà phýsin "segundo a natureza" (VI 4, 9. 11. 13; 5, 1; 6, 2. 7; 9, 13 bis; $10,3.4 ; 51,4)$, p. ex., ao explicar como as constituiçôes políticas se transformam segundo a natureza; ora empregando o advérbio physikôs "de modo natural" (VI 10, 2), p. ex., ao contar que Licurgo entrevira que as transformações das constituições eram levadas a cabo de modo natural. Pois,
8. cf. XII 10, 3: ut illa prope rudia ac uelut futurae mox artis primordia.

9. cf. XII 10, 10: Mediam illa formam.

10. cf. XII 10, 4: plurimum arti addiderunt.

11. cf. XII 10, 6: Floruit; 10, 11: efflorescat.

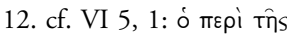

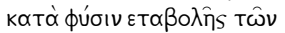

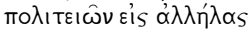

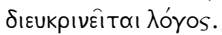

13. cf. VI 9, 10:

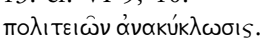

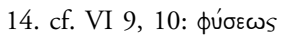
oikovouía. 


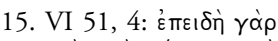

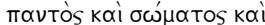

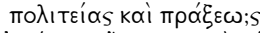

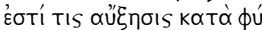

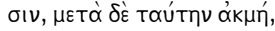

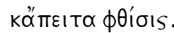

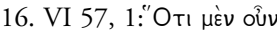

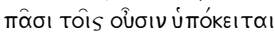

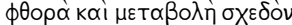

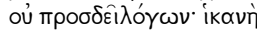

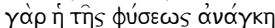

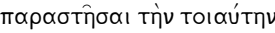
míotiv.

17. Arstt. An. II 415 a

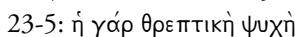

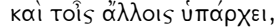

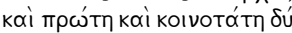

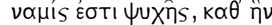

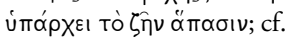
III 432 b 8-11.

18. Arstt. An. II 415 b

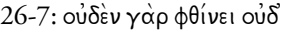

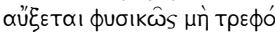

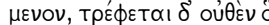

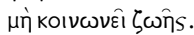

19. Arstt. An. III 434 a 22-6: Trìv $\mu \varepsilon \dot{v}$ oûv

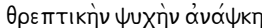

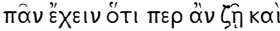

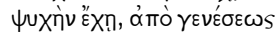

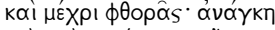

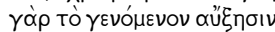
हैX

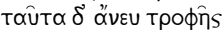

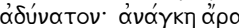

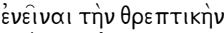

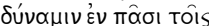

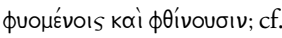
I 411 a 29-30: Yívetaı dè

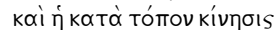

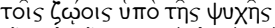

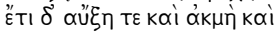
$\phi \theta^{\prime}$ íls.

20. Arstt. An. II 412 a

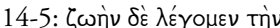

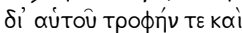

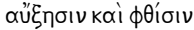

destarte, Políbio equipara o modo como as coisas humanas nascem umas das outras à maneira como as coisas naturais são geradas umas das outras. De fato, diz que, após deteriorarem-se todos os ofícios e artes, a multidão dos homens cresce de novo como que de sementes, assim como ocorre aos outros seres vivos (VI 5, 4-7). Assim também, ao comparar a constituição dos romanos com a dos cartagineses (VI 51-6), lembra que, de todo corpo, constituição política, ação, existe o desenvolvimento segundo a natureza; depois deste, o florescimento; e, em seguida, a deterioração. ${ }^{15}$ Daí, tendo concluído a comparação, justifica-se, dizendo que não é necessário insistir em que para todos os seres há deterioração e transformação, pois basta a necessidade natural para sustentar essa crença. ${ }^{16}$

Logo, a maneira como Políbio, Cícero, Quintiliano e, daí, Suetônio concebem a história de artes e ofícios humanos revela-se fisicista ou naturalista, uma vez que a descrevem como a vida dos seres vivos que primeiro nascem, e daí crescem, e daí florescem, e enfim perecem. De fato, é assim que Aristóteles (384-322 a.C.), no Da alma, descreve a vida de qualquer ser vivo, homem, animal ou vegetal, como a sucessão do nascimento, desenvolvimento, florescimento e deterioração. Antes de tudo, vincula a vida à alma nutritiva, que, como ensina, é a primeira e a mais comum potência da alma, por meio da qual o viver subsiste em todos. ${ }^{17}$ Pois nada se deteriora nem se desenvolve de modo natural que não tenha sido nutrido; nada se nutre, porém, que não comungue na vida. ${ }^{18}$ Daí, vincula à alma nutritiva o que é próprio do ser vivo, isto é, o desenvolvimento, florescimento e deterioração. Pois, como argumenta, é necessário que o que é gerado tenha desenvolvimento, florescimento, deterioração; isso, porém, é impossível sem nutrição; logo, é necessário que a potência nutritiva resida em todos os que nascem e se deterioram. ${ }^{19}$ Por isso, ao distinguir entre os corpos naturais que têm vida, e os que não têm, Aristóteles chama vida a nutrição do ser por ele mesmo, o florescimento, a deterioração. ${ }^{20}$

Assim, pode-se concluir que Políbio, Cícero, Quintiliano e, daí, Suetônio se valem de conceitos fisicistas ou naturalistas para expor a história de artes ou ofícios humanos. De acordo com tal concepção, a história destes é 
um caminho para o aperfeiçoamento que se divide em quatro tempos, a saber: $1^{\mathrm{o}}$ no tempo do início (gr. arkhé; lat. initium) ou descoberta (gr. heúresis; lat. inuentio); $2^{\circ}$ no tempo do desenvolvimento (gr. aúxesis; lat. augmentum); $3^{\circ}$ no tempo da perfeição (gr. télos; lat. perfectio) ou florescimento (gr. akmé; lat. flos); $4^{\circ}$ no tempo da deterioração (gr. phthorá; lat. corruptio). De acordo com tal concepção, pois, a história das artes e ofícios humanos avança assim como a vida dos seres vivos, de maneira que a exposição de tal avanço seja antes biográfica que histórica. Por isso, não é só de modo figurado, como antes se sugeriu, mas já de modo próprio que se pode dizer que Suetônio expõe o bios "vida ou biografia" da gramática em Roma.

\section{B) A BIOGRAFIA DOS GRAMÁTICOS}

Na segunda parte da obra, por sua vez, Suetônio expõe a biografia de vinte gramáticos. A expressão com que abre aquela, porém, é mais precisamente a de clari professores "professores ilustres" (4,11). Logo, Suetônio expõe a biografia de vinte gramáticos que não só escreveram sobre sua arte no ócio, mas a ensinaram por ofício. De fato, no fim da primeira parte, tendo já narrado a introdução, desenvolvimento e florescimento da gramática em Roma, Suetônio ensina que já então estavam discriminadas as "profissões" do gramático e do rétor (cf. 4, 7: iam tum discretis professionibus), de modo que aquele ensinasse até ao ponto de entregar os meninos a este $(4,7)$. Daí, na segunda parte, expõe, mais precisamente, a biografia dos gramáticos que foram "professores de gramática" (cf. 9, 2: professores; 9, 7: grammaticum professorem), isto é, que "professaram" gramática (cf. 9, 1: professus), exerceram a "profissão de gramático" (cf. 8, 1: in professione grammatica).

Não é por outra razão que Sévio Nicánor é o primeiro biografado, senão porque, justamente, foi o primeiro a alcançar a fama e dignidade "por meio da ação de ensinar" (cf. 5, 1: docendo). Daí, não é por acaso que o verbo docere "ensinar" ocorra em quinze das vinte biografias $(5,1 ; 6,1$; 7, 2. 3; 9, 1. 5; 10, 3;11, 2;13, $1 ; 15,1 ; 16,1 ; 17,2 ; 18$, 2. $3 ; 19 ; 20,2 ; 23,2 ; 24,4)$, a designar a ação distintiva 
dos gramáticos biografados. Na verdade, já na primeira parte, o verbo docere ocorre quatro vezes $(1,2 ; 3,5.6 ; 4,6)$ - duas vezes, aliás, ao lado de um derivado seu, o substantivo doctor "docente", e uma vez, ao lado do substantivo grammaticus "gramático" -. Pois, ao esboçar o início da gramática em Roma, Suetônio refere-se ao ensino dos mais antigos dos "docentes" (cf. 1, 2: antiquissimi doctorum [...] - docuisse) e, ao narrar o florescimento da gramática na Cidade, refere-se ao ensino dos mais conhecidos "docentes" (cf. 3, 6: nonnulli de notissimis doctoribus [...] docuerunt); assim também, ao distinguir entre as profissōes do gramático e do rétor, refere-se ao ensino dos antigos "gramáticos" (cf. 4, 6: Veteres grammatici [...] docebant). Em contrapartida, aquele que recebe os ensinamentos do gramático é chamado discens "aprendiz" $(7,1 ; 17,1)$ ou discipulus "discípulo" (7, $5 ; 9,3 ; 17,2 ; 24$, 4; cf. 19), e a relação entre um e outro, disciplina "aprendizado" $(13,2)$.

Outro termo com que Suetônio designa a ação do gramático é o verbo praecipere "preceituar" $(10,3 ; 16,2$; cf. 22,3$)$, de modo que chame ao resultado da ação praeceptum "preceito" $(7,3 ; 10,6)$, e ao gramático mesmo, praeceptor "preceptor" $(10,2 ; 11,2 ; 17,2)$; daí, usa do verbo audire "ouvir", quando se refere àquele que recebe os preceitos do gramático $(10,3 ; 20,1 ;$ cf. 10,2 : auditor atque praeceptor). Na primeira parte da obra, porém, emprega o verbo praelegere "lecionar" (1, 2; cf. 16, 3) e a expressão legere apud aliquem "ler junto a alguém" $(2,4)$, para designar respectivamente a ação do docente e a do discente. De resto, Suetônio ainda alude ao papel de magister "mestre" (cf. 24, 4: magistri personam), desempenhado pelo gramático, e cita, ademais, uns versos de Fúrio Bibáculo, em que o termo é aplicado a Valério Catão $(11,4)$, e a tirada de um anônimo, em que é referido a Rêmio Palêmão $(23,6)$.

Ora, nesse contexto eminentemente pedagógico, alguns gramáticos chamam a atenção, justamente porque nem sempre exerceram o ofício de ensinar. Pompílio Andronico, após ter ensinado em Roma, mudou-se para Cumas e lá viveu no ócio, compondo muitas coisas $(8,2)$. Valério Probo, por sua vez, nunca ensinou de modo que fizesse o papel de mestre, e assim teve não tanto discípulos quanto seguidores $(24,4)$. Assim também, alguns 
gramáticos sobressaem entre outros justamente por seus métodos de ensino. Orbílio Pupilo sobressai por ter exagerado no método tradicional, isto é, na palmatória..., como testemunham Horácio e Domício Marso, citados por Suetônio - aquele, a chamar Orbílio de "palmatório", e este, a rememorar aqueles que o gramático castigava com a férula e o açoite $(9,3)$-. Vérrio Flaco, por sua vez, sobressai por ter instituído um método inovador de ensino; pois, para exercitar os engenhos dos aprendizes, costumava lançar os de mesma idade uns contra outros, após ter-lhes proposto não só a matéria sobre a qual deveriam escrever, mas também o prêmio - em geral, algum livro raro - que o vencedor receberia $(17,1)$.

Suetônio também menciona o local de ensino. Ora, uma vez que, em regra, foram libertos, os gramáticos biografados exerceram a docência, primeiro, em casa de algum senhor e, depois, em casa sua; Antônio Gnifão, por exemplo, ensinou primeiro em casa de Júlio César, depois em sua própria casa $(7,2)$. Porém, embora um e outro ilustre, salta à vista a diferença entre a casa do senhor e a do gramático - aquela, em geral, ilustre, e esta, humilde -. Pois, de um lado, conta-se que Pompeio Lenéio ensinou em Carinas junto ao templo de Telúrica, lá onde estivera a casa dos Pompeios $(15,1)$, e Vérrio Flaco ensinou no átrio da casa de Cátulo que era então parte do Palácio $(17,2)$. De outro lado, conta-se que Orbílio Pupilo habitou debaixo de telhas $(9,1)$, e Valério Catão viveu recolhido a uma choça $(11,4)$, e Lúcio Crassício ensinou numa edícula $(18,2)$. Não poucos gramáticos, porém, foram bem-sucedidos, tanto que chegaram a abrir escola (cf. 16, 2: scholam aperuit). A palavra com que Suetônio designa o local de ensino é, em regra, schola "escola", palavra de origem grega, que ocorre em oito das vinte biografias $(6,2 ; 7,4 ; 8,1 ; 15,1 ; 16,2$; $17,2 ; 18,3 ; 23,1.5)$. Na primeira parte, porém, emprega uma vez aquela $(3,4)$, e outra, ludus "estabelecimento", palavra propriamente latina (cf. 4, 10: e grammatici [...] ludo). Mais que isso, ao narrar o florescimento da gramática em Roma, Suetônio conta que as escolas se multiplicaram dentro e fora da Cidade e, ademais, atraíram a atenção dos varōes mais ilustres, de modo que se produzisse a carestia dos preços e dos honorários dos gramáticos - bem 
entendido, do preço dos escravos, e dos honorários dos libertos - (3, 4-6). Em suma, segundo Suetônio, os sinais do florescimento do estudo da gramática em Roma são, de um lado, a qualidade e o número dos ouvintes e, de outro, os preços e os honorários dos preceptores.

Ao dizer quão ilustres e quão numerosos foram os ouvintes dos gramáticos, Suetônio emprega expressões tais como: multi et clari "muitos e ilustres" e multi et nobiles "muitos e nobres", como complemento de verbos tais como: praecipere "preceituar" (cf. 10, 3: praecepisse autem multis et claris iunenibus) e docere "ensinar" (cf. 11, 2: docuit multos et nobiles; 18, 3: et doceret [...] multos ac nobiles). Às vezes, nomeia os varões ilustres que seguiram as lições do gramático, a saber: Cícero, que freqüentou a escola de Antônio Gnifão (7, 4); Ápio Cláudio e Pulcro Cláudio, de que Ateio Filólogo foi preceptor $(10,3)$; Bruto e Cássio, que foram ensinados por Estabério Erote $(13,1)$; a esposa de Marco Agripa, que foi ensinada por Cecílio Epirota (16, 1); os netos de Augusto, dos quais Vérrio Flaco foi eleito preceptor $(17,2)$; Iulo Antônio, que foi ensinado por Lúcio Crassício $(18,3)$. Quanto ao número dos alunos, alguns gramáticos chamam a atenção, porque, graças a alguma condição privilegiada, puderam abster-se de ensinar o grande número. Cecílio Epirota foi preceptor de poucos, e tão-só de adolescentes, de nenhum pretextado, a não ser que não pudesse negar seu ofício ao pai de algum (16, 2-3); Vérrio Flaco mudouse para o Palácio a fim de ensinar os netos de Augusto, sob a condição de não receber mais nenhum discípulo $(17,2)$; Valério Probo costumava admitir um e outro ou, quando muito, três ou quatro nas horas vespertinas e, deitado, ler alguma coisa em meio a conversas longas e ademais banais, e isso bem raramente $(24,4)$. Alguns, porém, apesar de outros encargos, não se furtaram a ensinar o grande número; é o caso de Júlio Higino, que, apesar da incumbência de presidir à Biblioteca Palatina, não deixou de ensinar muitíssimos $(20,2)$.

Quanto aos preços e honorários, Suetônio explica que o valor venal do gramático escravo oscilava de acordo com a competência gramatical deste $(4,5)$. Daí talvez se pode inferir que isso de Caio Melisso ter sido dado de presente como gramático a Mecenas, significa que o senhor do escravo tinha 
alto apreço por este $(21,2)$. Por outro lado, os honorários do gramático liberto nem sempre eram elevados e, ademais, estavam sujeitos à inadimplência dos pais dos alunos... Orbílio Pupilo teria mesmo escrito um livro em que se queixasse dos prejuízos sofridos pelos professores por causa da negligência e rodeios dos pais $(9,2)$. Alguns, porém, dotados de alguma natureza superior, não obrigavam os pais a pagar. Antônio Gnifão, de natureza cordata e fácil, nunca ajustou os seus honorários, e por isso, na verdade, conseguiu mais, graças à generosidade dos aprendizes $(7,1)$; Estabério Erote fora dotado de tão grande honestidade que, nos tempos de Sula, teria recebido no aprendizado, de graça e sem honorários, os descendentes dos proscritos $(13,2)$. Alguns, porém, recebiam somas elevadas por seu ensino. Pompeio Lenéio sustentou-se com a sua escola, de tal modo que pôde devolver ao seu senhor o preço que este havia pago por ele (15, 1-3); Vérrio Flaco mudou-se para o Palácio com a escola inteira e recebeu 100.000 sestércios por ano $(17,2)$; Rêmio Palêmão tirava 400.000 sestércios por ano da sua escola $(23,5)$.

\section{TRADUÇÃO}

A seguir, apresenta-se tradução anotada do $D e$ grammaticis. A tradução foi elaborada a partir do texto latino estabelecido por Marie-Claude Vacher (SUÉTONE. Grammairiens et rhéteurs. Paris: Les Belles Lettres, 1993). O texto da tradução apresenta acréscimos: a) entre colchetes: a.1) palavra ou expressão que ou se subentende no original, e se explicita na tradução, ou se admite lá, e se acrescenta aqui; a.2) tradução de palavra ou expressão grega empregada no original e reproduzida na tradução; a.3) subtítulo ausente no original; b) entre parênteses: indicação completa de obra citada de modo parcial no original. As notas, por sua vez, procuram informar, quanto possível, o nome completo das personagens ou a datação destas e também dos eventos, ações e governos mencionados na obra. Além disso, remetem às seçóes em que o nome de uma personagem eventualmente se repete na obra. 


\section{Caio Suetônio Tranqüilo, Dos gramáticos}

\section{[A GRAMÁTICA EM ROMA]}

21. Lívio Andronico (c. 284 c. -204 a.C.).

22. Quinto Ênio (239169 a.C.); cf. "Seções 2 e $8 "$

23. Aristarco de Samotrácia (c. 217 - c. 145 a.C.).

24. 168 a.C.

25. cf. "Seções 1 e 8".

26. fl. c. 135 a.C.

27. Cneio Névio (c. 270 - c. 200 a.C.)
1. A gramática em Roma não estava sequer em uso outrora, nem em apreço nenhum, cidade ainda então rude e ademais belicosa, e que ainda não tinha muito tempo, bem entendido, para as disciplinas liberais. Também o início dela se mostrou modesto, se é que os mais antigos dos docentes, que eram eles mesmos tanto poetas como semigregos - falo de Lívio ${ }^{21}$ e Ênio, ${ }^{22}$ que, sabe-se, em casa e fora ensinaram em ambas as línguas -, nada mais faziam que traduzir os gregos ou, se algo eles mesmos tivessem composto em latim, lecioná[-lo]. Pois, quanto àquilo que não poucos contam: que foram editados por Ênio dois livros sobre as letras e sílabas, bem como sobre os metros (frg. Funaioli, 101-3), Lúcio Cota argumenta com justiça, dizendo que não são do poeta, mas de um Ênio posterior, de que se referem ainda uns volumes sobre a disciplina do augúrio (frg. Funaioli, p. 411).

2. O primeiro, pois, a introduzir na cidade o estudo da gramática foi, quanto podemos opinar, Cratete de Malo, contemporâneo de Aristarco, ${ }^{23}$ que, enviado ao senado ${ }^{24}$ pelo rei Átalo entre a segunda e a terceira guerra púnica quando da morte mesma de Ênio, ${ }^{25}$ como tivesse fraturado a perna ao escorregar numa boca de bueiro na região do Palácio, fez sucessivamente o maior número de akroáseis ["audiçōes"] e dissertou assiduamente por todo o tempo de sua delegação, assim como de sua convalescência, e daí aos nossos serviu de exemplo para imitar. Imitaram[-no], todavia, ao ponto tão-só de refundir com alguma diligência os carmes ainda pouco divulgados quer de amigos falecidos quer de outros, dos quais tivessem apreciado [os carmes], e também fazê-los conhecidos dos demais ainda por meio de leitura e comentário - como Caio Otávio Lampadião ${ }^{26}$ [refundiu] a Guerra púnica de Névio, ${ }^{27}$ a qual, apesar de ter sido exposta num único volume e em escrita contínua, ele dividiu em sete livros; como posteriormente Quinto Vargunteio [fez conhecidos] os Anais de Ênio, os quais ele proferia em meio a grande freqüência em dias certos; como 
Lélio Arquelau e Vécio Filócomo [fizeram conhecidas] as Sátiras de Lucílio, ${ }^{28}$ familiar seu, as quais Pompeio Lenéio ${ }^{29}$ declara ter lido junto a Arquelau, [e] Valério Catão, ${ }^{30}$ junto a Filócomo (frg. Funaioli, p. xiii, 51-2, 142, 403).

3. Aparelharam e desenvolveram sob todo aspecto a gramática Lúcio Élio Lanuvino ${ }^{31}$ e o genro de Élio, Sérvio Clódio, ${ }^{32}$ um e outro cavaleiro romano e de grande e vária experiência tanto no ensinamento como na coisa pública. Élio foi de duplo cognome; pois era chamado tanto Preconino, porque o pai dele exercera o preconício, como Estilão, porque soía escrever para cada um dos mais nobres os discursos oratórios [destes], tão partidário dos aristocratas que acompanhou até o exílio ${ }^{33}$ Metelo Numídico. ${ }^{34}$ Sérvio, como tivesse tomado emprestado por fraude o livro ainda não editado do genro e, por ter sido repudiado por isso, se tivesse retirado da Cidade por vergonha e desgosto, foi acometido pela doença da gota e, por não suportá-la, ungiuse os pés com veneno e necrosou[-os] de modo que vivesse com essa parte do corpo como que semimorta.

Depois disso, tanto o prestígio da arte [gramatical] como o cuidado com ela cresceram mais e mais, de modo que nem sequer os varôes mais ilustres se tenham abstido de eles mesmos escrever algo sobre ela, e de modo que na cidade tenham existido, conta-se, mais de vinte escolas concorridas em certos momentos. $\mathrm{Na}$ verdade, tamanhos [eram] os preços dos gramáticos, e tão grandes os honorários, que consta que Lutácio Dáfnide, ${ }^{35}$ que Lévio Melisso diz Panòs agápema ["objeto de estima de Pã"] por chalaça do nome, foi comprado por Quinto Cátulo ${ }^{36}$ por 700.000 moedas e daí foi rapidamente alforriado; que Lúcio Apuleio foi alugado por 400.000 [moedas] anuais por Efício Calvino, cavaleiro romano mui rico, para que ensinasse em Osca (frg. Funaioli, p. xiii-xiv). Pois também nas províncias a gramática penetrara, e daí não poucos dentre os mais conhecidos docentes ensinaram no exterior, sobretudo na Gália togada, entre os quais Otávio Teucro e Sescênio Iaco e Ópio Carete - este, na verdade, até o fim da vida e quando já não só no andar desfalecesse, mas também na visão -.

4. A designação de grammatici ["gramáticos"] prevaleceu pelo costume grego, mas no início eram chamados [em latim] litterati ["letrados"]. Também Cornélio
28. Caio Lucílio (c. 180 c. 102 a.C.); cf. "Seção $14 "$.

29. cf. "Seção 15 ".

30. cf. "Seções 4 e 11 ”.

31. c. 154 - c. 74 a.C.

32. m. c. 60 a.C.

33. 100 a.C.

34. Quinto Metelo Numídico (c. 160 - 91 a.C.).

35. n. c. 130 a.C.

36. Quinto Lutácio Cátulo (n. c. 150 a.C.); cf. "Seção 17". 
37. c. 100 - c. 25 a.C.

38. Marco Valério Messala Corvino (c. 64 a.C. - c. 8 d.C.).

39. Marco Fúrio Bibáculo (n. 103 a.C.); cf. "Seções 9 e 11 ". 40. cf. "Seção 11".

41. cf. "Seçōes 2 e 11". 42. cf. "Seçōes 8, 9 e 19".
Neto, ${ }^{37}$ no livrinho em que distingue litteratus ["letrado"] de eruditus ["erudito"], afirma que vulgarmente, na verdade, são designados litterati ["letrados"] os que podem ou dizer ou escrever algo com cuidado e com agudeza e ciência; por outro lado, que propriamente é para designar assim os intérpretes dos poetas, que são nomeados grammatikoi ["gramáticos"] pelos gregos (frg. Funaioli, p. 410). Messala Corvino $^{38}$ revela em certa epístola que esses mesmos foram freqüentemente chamados litteratores ["letradores"], ao dizer que ele nada tem que ver com Fúrio Bibáculo, ${ }^{39}$ nem tampouco com Tícidas ${ }^{40}$ ou com o letrador Catão - alude, sim, indubitavelmente, a Valério Catão, ${ }^{41}$ conhecidíssimo poeta e ao mesmo tempo gramático - (frg. Funaioli, p. 506-7). Há os que distingam litteratus ["literato"] de litterator ["letrador"], como os gregos [distinguem] grammatikós ["gramático"] de grammatistés ["gramatista”] e aquele, na verdade, têm na conta de absolutamente douto, este, de modestamente. A opinião de tais Orbílio ${ }^{42}$ confirma-a ainda com exemplos. Pois, de fato, afirma que, entre os antepassados, quando a famulagem de alguém era posta à venda, não sem mais soíam inscrever litteratus ["letrado"] na placa de um, mas litterator ["letrador"], como que não perfeito nas letras, mas imbuído [nelas] (frg. Funaioli, p. 135).

Os antigos gramáticos ensinavam retórica também, e assim se referem comentários de muitos [deles] sobre ambas as artes. Calculo que foi segundo tal costume que os pósteros também, ainda que já então discriminadas as profissões [do gramático e do rétor], quer retiveram quer instituíram eles mesmos, não obstante, certos gêneros de adestramento para preparar a eloqüência, como problemas, paráfrases, alocuçôes, etiologias e ainda outras desse gênero, para que, bem entendido, os meninos não fossem entregues aos rétores de todo secos e também áridos. Tais [gêneros de adestramento], na verdade, vejo que já se omitem pela indolência de certos [meninos] e pela falta de facúndia, pois por fastio eu não pensaria. Lembro-me de que, na verdade, sendo eu jovenzinho, certo [menino], de nome Príncipe, soía num dia declamar, no outro disputar; em não poucos dias dissertar na verdade de manhã, declamar depois do meio-dia após afastar o púlpito. Eu ainda ouvia que, à época 
dos [meus] pais, certos [meninos] haviam passado imediatamente do estabelecimento do gramático ao fórum e, ademais, haviam sido aceitos no número dos mais distintos patronos.

Os professores ilustres, e de que, ao menos por nós, possa ser apresentado algo, foram aproximadamente os seguintes.

\section{[Os GRAMÁTICOS EM ROMA]}

5. Sévio Nicánor foi o primeiro a alcançar a fama e dignidade ensinando e fez, além de comentários, de que todavia a maior parte, diz-se, fora tomada emprestada, uma sátira também, em que indica por meio destas palavras que era liberto e ademais de cognome duplo:

Sévio Nicánor, liberto de Marco, negará;

Sévio ... Nicánor . . ., o mesmo que Marco, ensinará (frg. Baehrens, p. 294).

Há os que contem que ele se retirou para a Sardenha por causa de certa má fama e lá findou seus dias.

6. Aurélio Opilo, liberto de certo epicureu, ensinou primeiro filosofia, depois retórica, por último gramática. Após ter deixado porém a [sua] escola, seguiu para a Ásia com Rutílio Rufo ${ }^{43}$ após este ter sido condenado; ${ }^{44}$ lá mesmo, em Esmirna ... e envelheceu ao mesmo tempo [que Rutílio Rufo], e compôs uns tantos volumes de erudição vária, dos quais nove de um único conjunto. Tais [livros], pois que teria julgado os escritores [prosaicos] e também os poetas sob a clientela das Musas, afirma que foi a partir do número e designação das divindades que, não absurdamente, tanto os fez como denominou (frg. Funaioli, p. 86-8). Advirto de que o cognome dele está escrito com uma única letra ["l" (Opilus)] em mais de um catálogo e título; na verdade, ele mesmo o expressa com duas [letras "l" (Opillus)] no acróstico de um livrinho denominado Pínax ["Prancha"] (frg. Funaioli, p. 87).

7. Marco Antônio Gnifão, ${ }^{45}$ nascido livre na Gália, mas exposto, após ter sido alforriado e formado por seu

43. m. post 78 a.C.

44. 92 a.C.

45. cf. "Seções 8 e 10". 
46. Caio Júlio César (101-44 a.C.); cf. "Seção 20 ".

47. Marco Túlio Cícero (106-43 a.C.); cf. "Seções 9, 14 e $16 "$

48. 66 a.C.

49. cf. "Seção 10". 50. cf. "Seções 7 e 10".

51. cf. "Seções 1 e 2".

52. cf. "Seções 4, 9 e 19".

53. n. 113 a.C.; cf. "Seçōes 4, 8 e 19". criador - em Alexandria, na verdade, na intimidade de Dionísio Escitobraquíáo, como contam alguns, o que, na verdade, eu não creria sem mais, já que mal coincide a conta dos tempos -, foi, diz-se, de grande engenho, de singular memória, não menos douto em grego que em latim; além disso, de natureza cordata e fácil; e nunca ajustou os [seus] honorários, e por isso conseguiu mais, graças à generosidade dos aprendizes. Ensinou primeiro na casa do divino Júlio, ${ }^{46}$ ainda menino [este]; depois, na sua [casa] particular. Ensinou, porém, retórica também, de modo que ministrasse os preceitos da eloqüência cotidianamente, não declamasse, na verdade, senão nos dias de feira. Afirmam que a escola dele foi freqüentada por varôes ilustres também - entre esses, por Marco Cícero, ${ }^{47}$ ainda quando [este] se desempenhasse da pretura ${ }^{48}-$. Escreveu muito, ainda que não tenha ultrapassado o qüinquagésimo ano de vida - aliás, Ateio Filólogo ${ }^{49}$ conta que ele deixou tão-só dois volumes acerca da língua latina, pois os demais escritos seriam dos discípulos dele, não dele mesmo, nos quais se encontraria algures o nome seu também, como este . . (frg. Funaioli, p. 99, 137).

8. Marco Pompílio Andronico, de nacionalidade síria, era tido por algo indolente na profissão de gramático, pela [sua] dedicação ao grupo epicureu, e pouco idôneo para tutelar uma escola. E assim, como visse que na Cidade era posto abaixo não só de Antônio Gnifão, ${ }^{50}$ mas dos demais, ainda piores, mudou-se para Cumas e lá viveu no ócio e compôs muitas coisas - na verdade, tão sem recursos e indigente, que foi obrigado a vender a alguém por 16.000 moedas aquele opúsculo seu dos élegkhoi ["refutações"] dos Anais de $\hat{E}_{n i o}{ }^{51}$ (frg. Funaioli, p. 101), os quais livros, após terem sido abafados, Orbílio ${ }^{52}$ diz que os comprou e cuidou para eles serem divulgados sob o nome do autor (frg. Funaioli, p. 134) -.

9. Lúcio Orbílio Pupilo, ${ }^{53}$ de Benevento, abandonado com a morte dos pais, assassinados em emboscada de inimigos num único e mesmo dia, primeiro foi ordenança de magistrados, depois serviu na Macedônia no cornículo, logo na cavalaria, e, após ter-se desempenhado do serviço militar, retomou os estudos, que abordara não superficialmente já desde menino, e daí, após ter sido 
professor por muito tempo na [sua] pátria, no [seu] qüinquagésimo ano enfim, mudou-se sob o consulado de Cícero $^{54}$ para Roma e [lá] ensinou com fama maior que o provento. Pois, de fato, já mui velho, confessa em certo escrito ser pobre e habitar debaixo de telhas (frg. Funaioli, p. 134). Editou ainda livro que tem por título ...., que contém queixas sobre os prejuízos a que os professores seriam suscetíveis pela negligência ou rodeios dos pais (frg. Funaioli, p. 135). Foi, porém, de natureza acerba, não só contra os antisophistaí ["adversários sofistas"], que dilacerou em toda ocasião, mas ainda contra os discípulos, como aludem tanto Horácio, ${ }^{55}$ ao designá-lo como "palmatório" (Hor. Ep. II 1, 69-71), quanto Domício Marso, ${ }^{56}$ ao escrever:

os que Orbílio acaso com férula castigou e com açoite (frg. Baehrens, p. 346).

E nem mesmo varôes importantes se absteve de insultar, se é que, ainda desconhecido, como desse testemunho num julgamento freqüentado, após ter sido perguntado por Varrão, ${ }^{57}$ o advogado da parte contrária, sobre o que então fazia, e de que arte usava [para viver], respondeu que levava corcundas do sol à sombra, porque Murena era corcunda. Viveu quase até o centésimo ano de vida, tendo já perdido a memória muito antes, como ensina o verso de Bibáculo: ${ }^{58}$

onde, pois, está Orbílio, das letras oblívio? (frg. Baehrens, p. 318).

Exibe-se em Benevento uma estátua dele, no Capitólio, do lado esquerdo, em mármore, à maneira de [alguém] sentado e também paliado, com dois escrínios postos ao lado. Deixou um filho, Orbílio, também este professor de gramática.

10. Lúcio Ateio Filólogo, ${ }^{59}$ liberto, nasceu em Atenas. Ateio Capitão, ${ }^{60}$ jurisconsulto conhecido, afirma que esse foi rétor entre gramáticos, gramático entre rétores. Acerca do mesmo, Asínio Polião, ${ }^{61}$ no livro em que repreende os escritos de Salústio ${ }^{62}$ de estarem impregnados de demasiada afetação de palavras arcaicas, conta isto: "Para isso, prestoulhe ajuda sobretudo certo Ateio Pretextado, [primeiramente] nobre gramático latino, depois ouvinte e ademais preceptor

54. 63 a.C.; cf. "Seções 7, 14 e $16 "$

55. Quinto Horácio Flaco (65-8 a.C.).

56. cf. "Seção 16".

57. Aulo Terêncio Varrão Murena (n. c. 56 a.C.).

58. cf. "Seçôes 4 e 11".

59. c. 105 a.C. - post 29

a.C.; cf. "Seção 7".

60. Caio Ateio Capitão (c. 30 a.C. - 22 d.C.); cf.

"Seção 22".

61. Caio Asínio Polião (76 a.C. -4 d.C.).

62. Caio Salústio Crispo (86-35 a.C.); cf. "Seção $15 "$. 
63. cf. "Seção 7 e 8".

64. Ensinou os irmãos Cláudios entre 80 e 75 a.C., a saber: Ápio (9748 a.C.) e Pulcro (m. 52 a.C.), dos quais ainda teria sido companheiro na província entre 55 e 51

a.C.

65. Eratóstenes de Cirene (c. 276 - c. 196 a.C.).

66. n. c. 95 a.C.; cf. "Seções 2 e 4".

67. 82-80 a.C.; cf. "Seção 13 ". dos que declamavam, em suma nomeado por si mesmo Filólogo" (frg. Funaioli, p. 495-6). Ele mesmo escreveu a Lélio Hermas que possuía grande progresso nas letras gregas, e não pouco nas latinas; que ouvira Antônio Gnifāo ${ }^{63} \ldots$. ; que fora preceptor, porém, de muitos e ilustres jovens, entre os quais, dos irmãos Cláudios também: Ápio e Pulcro, dos quais ainda teria sido companheiro na província ${ }^{64}$ (frg. Funaioli, p. xx, 136). Parece que adotou a designação de Filólogo porque, assim como Eratóstenes, ${ }^{65}$ que foi o primeiro a reivindicar para si esse cognome, era considerado de ensinamento múltiplo e vário, o que absolutamente se vê dos comentários dele, ainda que restem pouquíssimos, a cuja opulência, todavia, outra epístola ao mesmo Hermas alude assim: "Lembrar-te-ás de recomendar a outros a nossa Hýle ["Selva"], que reunimos em 800 livros, como sabes, de todo gênero" (frg. Funaioli, p. 136-7). Cultivou posteriormente grande familiaridade com Caio Salústio e, após este falecer, com Asínio Polião, os quais, tendo-se arrojado a compor história, ele aparelhou: um, com um breviário de todas as coisas romanas, das quais elegesse as que quisesse; o outro, com preceitos relativos à regra da escrita. Pelo que, mais me admira que Asínio tenha crido que ele soesse palavras antigas e figuras colher de Salústio, já que sabe que lhe não aconselhava nada senão usar de linguagem conhecida, civil e própria, e evitar sobretudo a obscuridade de Salústio e a audácia [deste] nas metáforas (frg. Funaioli, p. 137).

11. Públio Valério Catão, ${ }^{66}$ como não poucos contaram, liberto de certo Bursenus, oriundo da Gália - ele mesmo, num livrinho que tem por título Indignação, afirma ter nascido livre e ter sido abandonado pequenino e, por isso, mais facilmente despojado do [seu] patrimônio com a licenciosidade dos tempos de Sula ${ }^{67}$ (frg. Funaioli, p. 1412) -, ensinou muitos e nobres [varões], e pareceu mui idôneo preceptor, sobretudo para os que visavam à poética, como, na verdade, se pode ver, por exemplo, destes versos:

o gramático Catão, Siren latina, o só a ter lido e ademais fazer poetas (frg. Baehrens, p. 317). 
Ele ainda escreveu, a par de livrinhos de gramática, poemas, de que se apreciam sobretudo a Lidia e a Diana (frg. Funaioli, p. 142). A Lidia é citada por Tícidas: ${ }^{68}$

o livro, dos doutos o maior cuidado, da Lidia (frg. Baehrens, p. 325);

a Diana, por Cina: ${ }^{69}$

permaneça por séculos a Dictina do nosso Catão (frg. Baehrens, p. 324).

Viveu até extremada velhice, mas em suma pobreza e quase falta de recursos, à [sua] choça humildemente recolhido, depois que cedera aos credores a [sua] vila de Túsculo, como assegura Bibáculo: ${ }^{70}$

Se acaso vêem a casa do meu Catão, as telhazinhas pintadas de vermelho e aqueles jardinzinhos do guardião Priapo, admiram-se: "Graças a que disciplinas conseguiu tamanha sabedoria aquele que três repolhozinhos, meia libra de farinha, dois cachos sob um único teto quase nutram até a suma velhice?” (frg. Baehrens, p. 317-8),

e ainda:

Há pouco, um tusculano, ó Galo, de Catão o credor, estava a vender na cidade inteira. Admirou-nos que o mestre único, o sumo gramático, o ótimo poeta pudesse resolver todas as questôes, fosse difícil desembaraçar-se de uma única letra.

Eis o coração de Zenódoto, eis o fígado de Cratete! (frg. Baehrens, p. 317).

12. Cornélio Epícado, liberto do ditador Lúcio Cornélio Sula ${ }^{71}$ e porta-voz no sacerdócio augural, foi muito benquisto também do filho dele, Fausto; ${ }^{72}$ por isso, nunca deixou de se apresentar como liberto de ambos. O livro, por sua vez, último, que acerca de suas coisas Sula deixara inacabado, ele mesmo o completou (frg. Funaioli, p. 103). 
73. Marco Júnio Bruto (85-42 a.C.).

74. Caio Cássio Longino (ante 85 - 42 a.C.).

75. cf. "Seção 11".

76. Cneio Pompeio o Grande (106-48 a.C.); cf. "Seção 15".

77. m. 49 a.C.

78. cf. "Seçôes 7, 9 e 16".

79. Públio Cornélio Dolabela (70-43 a.C.).

80. Tito Pompônio Ático (c. 112 - c. 32 a.C.); cf. "Seção 16".

81. cf. "Seção 2".

82. fl. c. 54 a.C.

83. Pompeio Lenéio (c. 100 a.C.); cf. "Seção 2".

84. cf. "Seção 15".

85. Pompeio faleceu em 48 a.C., e os filhos dele, em 35 a.C.

86. cf. "Seção 10".
13. Estabério Erote . . ., comprado do estrado e alforriado por causa do estudo das letras, ensinou, entre outros, Bruto ${ }^{73}$ e Cássio. ${ }^{74}$ Há os que contem que ele fora dotado de tão grande honestidade que, nos tempos de Sula, ${ }^{75}$ teria recebido no aprendizado, de graça e sem honorários, os descendentes dos proscritos.

14. Cúrcio Nícias ligou-se a Cneio Pompeio ${ }^{76}$ e a Caio Mêmio ${ }^{77}$ mas, como à esposa de Pompeio tivesse levado cartôezinhos de Mêmio sobre concúbito, entregue por ela, ofendeu Pompeio, e interditou-se-lhe a casa [deste]. Foi familiar de Marco Cícero ${ }^{78}$ também, em cuja epístola a Dolabela $^{79}$ lemos acerca dele isto:

Nada se empreende em Roma que eu pense que cuides em saber, a não ser que acaso queiras saber que atuo como juiz entre o nosso Nícias e Vídio. Um profere em dois versinhos, creio, uma pendência [financeira] de Nícias; o outro, [qual] Aristarco, põelhes obelós ["óbelo"]. Quanto a mim, como antigo crítico, hei de

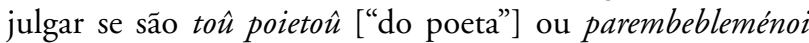
[“interpolados"]... (Cic. Fam. IX 10, 1);

assim também, [em cuja epístola] a Ático: ${ }^{80}$

O que acerca de Nícias escreves, se eu me portasse de modo que pudesse usufruir da humanidade dele, quereria antes de tudo ter aquele comigo, mas tenho por província a solidão e o retiro. Além disso, conheces a fragilidade, a delicadeza, os costumes de vida do nosso Nícias. Por que, pois, eu quereria ser molesto àquele, já que aquele me não pode ser encantador? A boa vontade dele, todavia, me é benquista (Cic. Att. XII 26, 2).

Os livros dele sobre Lucílio ${ }^{81}$ apreciou-os ainda Santra ${ }^{82}$ (frg. Funaioli, p. 383).

15. Lenéio, ${ }^{83}$ liberto de Pompeio o Grande ${ }^{84}$ e companheiro de quase todas as expedições [deste], após ele e os filhos dele falecerem, ${ }^{85}$ sustentou-se com a [sua] escola e ensinou em Carinas junto ao templo de Telúrica, na qual região estivera a casa dos Pompeios. E ademais mostrou-se de tão grande amor para com a memória do patrono que ao historiador Salústio, ${ }^{86}$ porque [este] o teria descrito como de rosto pudico sob ânimo desavergonhado, dilacerou com uma sátira muito acerba, designando[-o] como lástauros 
[“dissoluto"], comilão, frívolo e pau-d'água, e monstruoso pela [sua] vida e escritos, além disso, ladrão incultíssimo das palavras dos arcaicos e de Catão (frg. Funaioli, p. 4034). Conta-se, porém, que, menino ainda, após ter sido arrancado das cadeias, se refugiou na pátria ${ }^{87}$ e, após ter recebido as disciplinas liberais, devolveu ao [seu] senhor o seu preço, ${ }^{88}$ alforriado, na verdade, de graça pelo engenho e também pelo ensinamento.

16. Quinto Cecílio Epirota, nascido em Túsculo, liberto de Ático, ${ }^{89}$ cavaleiro romano, para quem são as epístolas de Cícero, ${ }^{90}$ como ensinasse a filha do [seu] patrono, casada com Marco Agripa, ${ }^{91}$ por ter sido suspeito de algo com ela e por isso afastado, dirigiu-se a Cornélio Galo ${ }^{92}$ e viveu junto [com este] do modo mais familiar, o que Augusto ${ }^{93}$ objetou, entre as mais graves incriminações, ao próprio Galo. Em seguida, após a condenação e morte de Galo, abriu uma escola, mas de modo que fosse preceptor de poucos e tão-só de adolescentes, de nenhum pretextado, a não ser se não pudesse negar esse ofício ao pai de algum. Foi o primeiro, diz-se, a ter disputado em latim de improviso, e o primeiro a ter começado a lecionar Vergílio ${ }^{94}$ e outros poetas novos, o que ainda o versículo de Domício Marso ${ }^{95}$ indica:

Epirota, de tenros vates nutriz (frg. Baehrens, p. 347).

17. Marco Vérrio Flaco, ${ }^{96}$ liberto, foi ilustre sobretudo pela maneira de ensinar; pois, de fato, para exercitar os engenhos dos aprendizes, soía lançar os de mesma idade uns contra outros, após ter[-lhes] proposto não só a matéria sobre a qual escreveriam, mas também o prêmio que o vencedor arrebataria - esse era algum livro, antigo, belo ou meio raro -. Por ter sido, por isso, eleito por Augusto ${ }^{97}$ também preceptor dos netos dele, ${ }^{98}$ mudou-se para o Palácio com a escola inteira, de modo que, na verdade, não aceitasse mais nenhum discípulo depois disso, e ensinou no átrio da casa de Cátulo ${ }^{99}$ que era então parte do Palácio, e recebeu 100.000 sestércios por ano. Partiu quando de idade avançada, sob Tibério. ${ }^{100}$ Possui estátua [sua] em Preneste na parte superior do fórum perto do hemikýklion ["hemicíclio"], em que publicara os fastos, ordenados por ele e talhados na parede de mármore.
87. 87 a.C.

88. 80-77 a.C.

89. cf. "Seção 14".

90. cf. "Seçōes 7, 9 e 14".

91. Marco Vipsânio Agripa (c. 63 - 12 a.C.).

92. Caio Cornélio Galo (c. 69 - 26 a.C.).

93. 63 a.C. - 14 d.C.; cf. "Seçôes 17, 19, 20 e 21".

94. Públio Vergílio Marão (70-19 a.C.); cf. "Seção $23 "$.

95. cf. "Seção 9".

96 c. $60 / 50$ a.C.

- c. $22 / 37$ d.C.

97 cf. "Seçōes 16, 19,20 e 21 ”.

98 Isto é, de Caio (20 a.C. -4 d.C.) e

Lúcio (17 a.C. - 2 d.C.).

99 cf. "Seção 3".

100 Tibério

Cláudio Nero (42 a.C. -

37 d.C.; princeps 14-37 d.C.); cf. "Seçôes 22 e $23 "$. 
101. fl. c. 10 a.C.

102. Iulo Antônio (n. 44 a.C.), filho de Marco Antônio (83-30 a.C.).

103. cf. "Seçōes 4, 8 e 9".

104. Escribônia (68 a.C. - c. 16 d.C.), filha de

Lúcio Escribônio Libão (praetor urbanus 80 a.C.), que fora a primeira esposa de Augusto (cf. "Seçōes $16,17,20$ e 21 ") entre 40 e 39 a.C.

105. n. c. 60 a.C.

106. cf. "Seções 16, 17, 19 e $21 "$

107. cf. "Seção 7". 108. 47 a.C.

109. Alexandro de Mileto (n. c. 105 a.C.), que esteve em Roma até 40 a.C.

110. A biblioteca foi fundada em 28 a.C.; então, Pompônio Macro foi encarregado de organizá-la, e a ele sucedeu Higino na presidência da biblioteca.

111. Públio Ovídio Nasão (43 a.C. 17/18 d.C.).

112. consul suffectus 4 d.C.

113. Caio Mecenas Melisso.
18. Lúcio Crassício, ${ }^{101}$ de raça tarentina, da classe dos libertos, de cognome Pásicles, logo mudou seu nome para Pansa. Esse inicialmente circulou na cena, enquanto ajuda os mimógrafos; em seguida, ensinou numa edícula, até que, após ter editado o [seu] comentário à Esmirna (frg. Funaioli, p. 524), se tornou de tal modo ilustre que escrevessem isto sobre ele:

Unicamente em Crassício Esmirna provou que acreditava; desisti, indoutos, de pedi-la em matrimônio.

Somente com Crassício disse que queria casar-se, ao qual, somente, se mostraram conhecidas as suas intimidades (frg. Baehrens, p. 348).

Mas, como ....e ensinasse já muitos e ademais nobres entre esses, a Iulo Antônio, filho do triúnviro ${ }^{102}$-, de modo que fosse comparado a Vérrio Flaco também, após ter deixado repentinamente a [sua] escola, mudou-se para o grupo do filósofo Quinto Séxtio.

19. Escribônio Afrodísio, escravo e ademais discípulo de Orbílio, ${ }^{103}$ logo resgatado e alforriado por Escribônia, filha de Libão, que fora a primeira esposa de Augusto, ${ }^{104}$ ensinou no tempo em que Vérrio [ensinou], em réplica a cujos livros sobre ortografia ainda escreveu, não sem perseguir os estudos e os modos dele (frg. Funaioli, p. 524-5).

20. Caio Júlio Higino, ${ }^{105}$ liberto de Augusto, ${ }^{106}$ de nação hispânica - não poucos pensam que foi alexandrino e por César ${ }^{107}$ conduzido a Roma em menino após a captura de Alexandria ${ }^{108}$-, tanto ouviu como imitou estudiosamente o gramático grego Cornélio Alexandro, ${ }^{109}$ que, por causa do conhecimento da antigüidade, muitos chamavam Poliístor; alguns, História. Presidiu à Biblioteca Palatina, ${ }^{110}$ e nem por isso deixou de ensinar muitíssimos, e foi muito familiar do poeta Ovídio ${ }^{111}$ e do cônsul, historiador Clódio Lícino ${ }^{112}$, que conta que ele partiu sobremodo pobre e foi sustentado, quanto viveu, por generosidade sua. Liberto desse foi Júlio Modesto, que seguiu as pegadas do patrono nos estudos e também no ensinamento.

21. Caio Melisso, ${ }^{113}$ nascido livre em Espolêcio, mas exposto por causa de desentendimento dos pais, recebeu estudos mais aprofundados graças aos cuidados e empresa 
do seu educador, e daí foi dado de presente como gramático a Mecenas. ${ }^{114}$ Embora de tal [Mecenas] visse que fosse benquisto e recebido à maneira de amigo, ainda que com a mãe a pleitear [a liberdade para ele], permaneceu todavia no estado de escravidão e pôs à frente da [sua] origem verdadeira a condição presente. Cedo alforriado por isso, passou ainda para o seio de Augusto. ${ }^{115}$ Por delegação de tal [Augusto], encarregou-se do cuidado de organizar as bibliotecas no Pórtico de Otávia. ${ }^{116} \mathrm{E}$, ademais, como ele mesmo conta, no sexagésimo ano de idade, decidiu compor os livrinhos das Inépcias, agora denominados Jocosidades, e completou cento e cinqüenta [deles], a que adicionou posteriormente outros também de obra diversa (frg. Funaioli, p. 538). Fez novo gênero de togadas também e denominou[-as] trabeadas (ib.).

22. Marco Pompônio Marcelo, inquisidor exigentíssimo da língua latina, em certa advocatura - pois às vezes defendia causas também -, a tal ponto perseverou em argüir o solecismo feito pelo adversário que Cássio Severo, ${ }^{117}$ após ter interpelado os juízes, pediu adiamento [da causa] para que o seu litigante empregasse outro gramático, "uma vez que ele pensa que há de ter controvérsia com o adversário, não acerca de direito, mas de solecismo". Esse mesmo, como tivesse repreendido uma palavra proveniente de um discurso oratório de Tibério, ${ }^{118}$ ao afirmar Ateio Capitão ${ }^{119}$ não só que aquela [palavra] era latina, mas que, se não fosse, havia de ser certamente dali em diante, "Capitão" insiste "mente; pois tu, César, podes conceder cidadania a homens, a uma palavra não podes". Que tenha sido outrora pugilista, Asínio Galo $^{120}$ revela-o neste epigrama contra ele:

Aquele que aprendeu o "cabeça à esquerda", glossémata ["palavras raras"] nos

preceitua. Com que cara? Com nenhuma - ou antes, [com a] de pugilista...-(frg. Baehrens, p. 360).

23. Quinto Rêmio Palêmão, de Vicêcia, criado de uma mulher, aprendeu primeiro, como contam, a tecelagem; depois, enquanto o filho do amo ele acompanha até a escola, as letras. Alforriado depois disso, ensinou em Roma e, ademais, ocupou o primeiro lugar entre os gramáticos, ainda
114. Caio Cílnio

Mecenas (70-8 a.C.).

115. cf. "Seções 16, 17, 19 e $20 "$

116. conditus post

23 a.C.

117. Tito Cássio Severo (exsul 12 d.C.; m. 34 d.C.).

118. cf. "Seçōes 17 e 23".

119. cf. "Seção 10".

120. Caio Asínio Galo Salonino (41 a.C. 33 d.C.). 
121. cf. "Seções 17 e 22”.

122. Tibério Cláudio Druso (10 a.C. 54 d.C.; princeps 41-54 d.C.).

123. Marco Terêncio Varrão (116-27 a.C.).

124. cf. "Seção 16". que mal-afamado por todos os vícios, e tanto com Tibério ${ }^{121}$ como, logo, com Cláudio ${ }^{122}$ a apregoarem publicamente que a ninguém era menos para entregar a formação de meninos ou jovens [que a ele]. Mas cativava os homens, se já pela memória das coisas, ainda mais pela facilidade da linguagem, e não só: ainda poemas fazia de improviso escreveu, na verdade, em metros vários e invulgares - (frg. Mazzarino, p. 72-3). De tamanha arrogância foi que designasse Marco Varrão ${ }^{123}$ como porco; se jactasse de com ele as letras tanto haverem nascido como haverem de morrer, de o seu nome haver sido posto não sem mais nas Bucólicas, mas por Vergílio ${ }^{124}$ pressagiar que algum dia havia de haver o juiz de todos os poetas e também poemas Palêmão (Verg. B. 3, 49-54). Vangloriava-se ainda de ladróes o haverem poupado, certa vez, por causa da celebridade do [seu] nome. Foi de tal modo indulgente com a luxúria que se lavasse mais de uma vez por dia, e lhe não fossem suficientes os [seus] gastos, ainda que recebesse 400.000 sestércios por ano da [sua] escola e, ademais, não muito menos dos bens familiares, em que era muito diligente, já que tanto dirigia oficinas de roupas prontas, como cultivava de tal modo os [seus] campos que consta assaz bem que uma vide, emparreirada pela mão dele, deu 360 uvas. Mas, sobretudo, abrasava-se nos desejos por mulheres até às infâmias da boca. Foi notado também pelo dito não desprovido de facécia, relatam, de certo [homem] que, em meio à turba, como não pudesse evitar, ainda que a fugir, o beijo que lhe dirigia [Palêmão], "Queres tu," insiste "mestre, sempre que vês alguém apressado, lambê[-lo]?”...

24. Marco Valério Probo, de Berito, pleiteou o cargo de centurião por muito tempo, até que se entregou aos estudos por desgosto. Lera na província certos velhos livrinhos junto ao gramatista, por perdurar lá, ainda então, a memória das antigüidades, e ainda não ter sido de todo abolida, como em Roma. Como esses desejasse repassar com maior diligência e, ademais, conhecer outros continuamente, embora advertisse em que todos [esses livrinhos] fossem desprezados e servissem mais de opróbrio aos que [os] liam do que de glória e fruto, permaneceu no [seu] propósito, não obstante, e cuidou de emendar e também pontuar e anotar, após reuni-los, muitos exemplares, tendo-se 
dedicado a essa só, e além disso a nenhuma parte da gramática. Esse possuiu não tanto discípulos quanto uns tantos seguidores; nunca, sim, ensinou de modo que fizesse o papel de mestre; soía admitir um e outro ou, quando muito, três ou quatro nas horas vespertinas e, deitado, ler alguma coisa em meio a conversas longas e ademais banais, e isso mui raramente. Editou demasiado poucas e exíguas coisas sobre algumas diminutas questiúnculas; deixou, porém, não modesta selva de observações acerca da língua antiga.

Enviado em janeiro de 2014 Aprovado em abril de 2014. 
